\title{
Impact of Job Clarity on Nurses' Job Satisfaction: A Moderating Role of Fairness Perception
}

\author{
Muhammad Asif Qureshi ${ }^{1}$, Karim Bux Shah Syed ${ }^{2}$, Noor Ahmed Brohi ${ }^{3}$, Arjumand Bano Soomro ${ }^{4}$, Tania \\ Mushtaque $^{4}$ \\ ${ }^{1}$ School of Business Management, College of Business, Universiti Utara, Malaysia \\ ${ }^{2}$ Institute of Business Administration, University of Sindh Jamshoro, Sindh, Pakistan \\ ${ }^{3} \mathrm{PhD}$ Candidate, Putra Business School, University Putra, Malaysia \\ ${ }^{4}$ Institute of Information and Computer Technology, University of Sindh, Jamshoro, Sindh, Pakistan \\ Correspondence: Karim Bux Shah Syed, Institute of Business Administration, University of Sindh Jamshoro, \\ Sindh, Pakistan.
}

Received: March 22, 2019

doi:10.5539/ibr.v12n4p187
Accepted: March 29, 2019

Online Published: March 29, 2019

\begin{abstract}
The main objective of this study was to ascertain the impact of job clarity on nurses' job satisfaction in the public hospitals of Sindh province of Pakistan. The results presented a valid and reliable measurement model so that a structural model could be built upon it for testing research hypotheses. Results indicate that job clarity has an insignificant impact on job satisfaction among nurses in Pakistan. Moreover, the fairness perception does not moderate; rather, it is found to be a strong predictor of nurses' job satisfaction. In other words, people have a lack of clarity about tasks, roles, and responsibilities, often end up affecting their outcomes. Therefore, it is recommended to strengthen the element of fairness in jobs to boost job satisfaction. HR policies and general policy makers in the organization have a greater role in this regards to ensure that the work and task are divided on fair grounds and so the rewards.
\end{abstract}

Keywords: job clarity, fairness perception, job satisfaction, Pakistan

\section{Introduction}

Nowadays healthcare system plays a vital role in the development and strengthening of the nation`s wellbeing across the globe (Swayne, Duncan, \& Ginter, 2012). The healthcare sector not only serves the basic needs but also provides opportunities for economic expansion (Mahmud \& Parkhurst, 2007). According to the Deloitte recent annual report, the global healthcare sector is becoming increasingly competitive where there is a growing need for a committed workforce (Deloitte, 2015). Along with this, job clarity is also a very important and crucial factor while predicting job satisfaction. According to Zeffane and Al-Zarooni (2008) job clarity is how individuals can clearly outline their job roles, expectations and responsibilities in the organization. Job clarity denotes to how employees have been communicated and guided towards the assigned responsibilities and what is expected from them in return (Jansen, Kerkstra, Abu-Saad, \& Van Der Zee, 1996).

According to the World Bank database (2016), Pakistan ranks $6^{\text {th }}$ in the world in terms of population and is listed amongst the under-developing economies. With a population of more than 191 millions, the nation is striving yet struggling in providing basic services and facilities to its people including healthcare, education, food, and security. Especially when it comes to health services, the majority of the population has no access to basic health facilities (Bhatti, Islam, Mirza, \& Hadi, 2015). In Pakistan, the health care sector is expanding since the last decade. The healthcare sector comprises both public and private sector hospitals whereby, there are around 1,142 hospitals, 5,499 dispensaries, 5,483 basic health units as per government report (Pakistan Economic Survey, 2015-16). According to the recent report, there are 90,276 registered nurses (Pakistan Economic Survey 2016-17) across the country which results in 1:2104 ratios with the total population (Bhatti et al., 2015). A study by Khaliq, Rehman, and Rashid (2011) argued that nearly 42 percent of the nurses were not satisfied with their jobs in Pakistan. The issue is more severe in public sector hospitals due to no job clarity (Kumar, Ahmed, Shaikh, Hafeez, \& Hafeez, 2013; Bushra, Usman, \& Naveed, 2011). In Pakistan, the nursing staff has a lot of responsibilities during their job. Sometimes the nurses have to give extra time or late duties as well. They are 
totally responsible for the health of their patients after the patients come from some surgery or after a doctor's treatment. Sometimes, nurses have responsibilities even more than doctors' responsibilities because their job role and job description is not clear. Their seniors ask them to stay ready for any type of task which is assigned to them during their duty time. This is one of the reasons which make them unsatisfied with their job. Therefore, job clarity is very important in every field and even in the field of nurses too for leading towards job satisfaction.

The aim of this study is examining the role of job clarity in nurses' job satisfaction with the moderating effect of fairness perception. Taken together, to bridge the aforementioned theoretical and practical gaps, a quantitative study is needed to analyze the impact of job clarity on the nurses' job satisfaction in the public hospitals of Pakistan. This study also attempts to investigate whether fairness perception moderates the relationship between job clarity and nurses' job satisfaction. The remaining part of the study consists of the following sections. Section 2 explains the literature review about the job clarity and job satisfaction. Section 3 describes the methodology. Section 4 clarifies the data analysis and discussion section, and section 5 presents the conclusions and policy recommendations.

\section{Literature Review}

Different features of representative job satisfaction have been investigated with the help of various examinations, illustrations, and observations by the the scholars. Previous empirical findings recommend that organizational work attributes such as job clarity, job autonomy, and other factors possess a considerable role in the development job satisfaction amongst the workforce (Konovsky \& Cropanzano, 1991; Wright \& Davis 2003; Chen, Gully, Eden, 2001; Boyt et al, 2001; Chu, Hsu, Price \& Lee, 2003; Chang, Li, Wu, Wang, 2010). Therefore, prominent researchers in the area have been critically appraised in the present study. These authors have reported that job clarity is essential prospects to boost job satisfaction. In the domain of job satisfaction, organizational factors possess significant value and importance which is why, a majority of the studies have attempted to underline how factors in this category can be of prominence for businesses across different occupational settings (Boyt et al, 2001).

Job clarity represents the degree to which required details are clear about the job and how the employee/worker needs to perform his/her job in a way that enhances efficiency and avoid wasting of time (Teas, Wacker, \& Hughes, 1979). In the same context, Kelly and Hise (1980) described job clarity that individual employee receives details and understanding about the job clarifying what they are expected to do and what they are not. Kim (2009) stated that job clarity is when tasks and expectations of the job are made clear to the employee. Job clarity was described as an understanding of the following role components: (a) goals of role efficiency, (b) attitude and behavior necessary for goal accomplishment, (c) role limitations, and (d) behavior predicted by those in roles counters (Meleis, 1975; Meleis \& Swendsen, 1978). Job clarity is defined as an understanding of job requirements and come up with performance fulfill job requirements as individually (Brief, Schuler \& Van Sell, 1981). Previous literature indicated that a high level of job clarity increases job satisfaction resulting in employees' loyalty and trustworthiness with the organization (Zeffane and Al Zarooni, 2008). Role clarity is an important factor to enhance the employee's job performance (Locke \& Latham, 2002). Role clarity reduces the unambiguity of employees and also decreases the risk of mistake during working (Ting, 1997). Furthermore, job clarity helps the employee to understand the job role.

On the other hand, lack of role clarity increases the job dissatisfaction and decreases performance (Kahn, Wolfe, Quinn, Snoek, \& Rosenthal, 1964; Kelly \& Hise, 1980). Due to lack of clarifications, the negative impact on the job ultimately affects the employee job satisfaction negatively. In the service sector, job clarity provides a chance to service providers to deliver services in a quick and better manner to their customers (Suan, \& Nasurdin, 2013). Terje, Göran, and Sander (2011) also defined when a service employee having a lack of role clarity its negative impact on the outputs are likely to happen such as involved employees may offer incorrect information, which leads to the inadequate services to the customers.

Particularly, job clarity is important for employees who are performance and satisfaction focused. According to Terje et al., (2011) job clarity is also significant in the services sector. Furthermore, indicated that a high level of role clarity brings confidence in the employees to perform better and meet the requirements of the customers. Therefore, when an employees' role is clear on what they are expected to do in their job, they are more likely to look with a positive mindset towards their work and show greater zeal to provide services to their customers (Suan, \& Nasurdin, 2013). Hence, an employee with a high level of role clarity is expected to deliver high-quality service to customers.

According to Troyer, Mueller, and Osinsky (2000) a higher level of job clarity, reduced the level of issues at job time. Bray and Brawley, (2002) outlined that clear role of employee motivated them to work beyond the 
expectation of the organization. In United Empire hospital nursing staff, Blumenthal, Lavender, \& Hewson (1998) Found that reduced job clarity results in unwanted effects for both company members and for organizational efficiency. Though more common in literature, there are limited positive effects of job clarity on efficiency (Singh, 1993). In fact, some studies have even shown a negative relationship between job clarity and purpose, and subjective measure of service quality (Wetzels, De Ruyter, \& Bloemer, 2000), showing that a limited amount of role ambiguity always gave the result of increased and better performance (Lyons, 1971).

Locke and Latham (2002) have underlined that job clarity provides clear outlines as to what is expected thus, resulting in employees` satisfaction with the job. Notably, Zeffane and Al-Zarooni (2008) have related it with organizational structuring whereby employee functions and expectations are rooted and mapped. Accordingly, Adams and Bond (2000) studied nurses and their job clarity and found that clarity concerns are critical for them to perform in a better manner and job satisfaction. Further exploration of the literature on job clarity has underlined inconsistent findings for the construct. According to Kroposki et al., (1999), there are job clarity is correlated with employee job satisfaction whereby, Smerek and Peterson (2007) outlined that job clarity is not correlated with job satisfaction. According to Kroposki et al. (1999) that role ambiguity and lack of information about the job which negatively influences job satisfaction. A study conducted by Smerek and Peterson (2007) that staff found insignificance relationship between job clarity and employees job satisfaction. Thus, the previous literature has varying outcomes about the relationship of job clarity and employee job satisfaction.

Based on the above literature, it is clear that job clarity is very essential for analyzing the impact on job satisfaction among nurses. The contrasting results (Tumulty, et al., 1994; Kroposki et al., 1999; Adams \& Bond, 2000; Smerek and Peterson, 2007) job clarity will be moderated in their relationship with nurses job satisfaction. Hence, the current study proposes that the relationship between job clarity will be moderated in their relationship with nurses` job satisfaction. Therefore, the current literature concludes the following proposed research model and hypotheses which are as follows.

\section{H1: Job Clarity is positively related to nurses`Job satisfaction}

\section{H2: Fairness perception moderates the relationship between Job clarity and Job satisfaction}

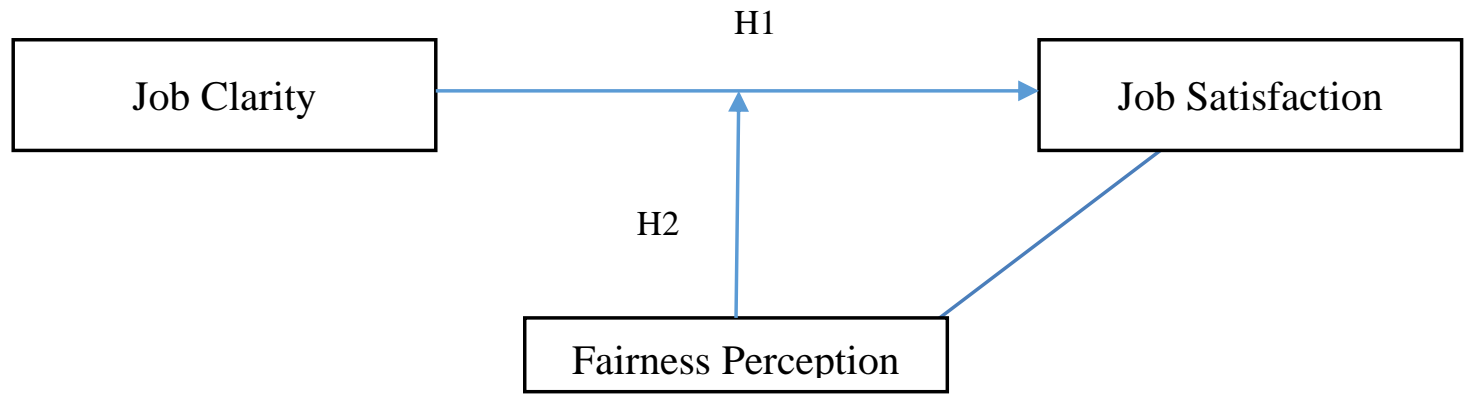

Figure 1. Conceptual Framework

\section{Methodology}

A sample consisting of 325 questionnaires gathered from the different parts of the Sindh province of Pakistan is used in this study. The data were collected during the span of 12 months from January 2015 to December 2015) through a survey transcribed in English. After the data screening, eleven items were removed on the basis of missing values. In addition, twenty one uni-variate outliers were identified and removed from the dataset. To identify the multivariate outliers, we applied the Mahalanobis distance critical Chi-square function at $\mathrm{p}<0.001$. We found thirteen multivariate outliers on this criterion. Therefore, after excluding 45 invalid responses, the final sample of 280 valid responses was used. The current study deployed a cluster sampling technique. The target population was segregated into groups based on areas and clusters (Kothari, 2004). Out of those clusters, a simple random sample from the groups was selected to respond. This was because the researcher attempted to gather the data on the number of nurses working in each hospital of Sindh province. Our sample includes all the public sector hospitals located in the province of Sindh, Pakistan. This is due to the fact that the researcher tried to acquire the data regarding the number of nurses working in each hospital of Sindh province. The current study covered all the public hospitals, located in Sindh Pakistan. Researcher requested the complete lists of nurses serving in the 43 public hospitals for conducting surveys. Notably, Sindh Health department and Health Ministry of Pakistan are the only government regulatory authorities for hospitals in the country but failed to give the 
complete details in this regard. In fact, the list was not available for two reasons. Firstly, the document was not updated, thus it could have provided inappropriate information about the number of doctors in each hospital of Sindh. The conclusions drawn in the present study are unbiased. We followed the guidelines of Dillman (1978) in fulfilling ethical standards. The present study has no biases in attaining any conclusion. The research followed the directions of Dillman (1978) in fulfilling ethical measures. The credentials of the respondents are taken care of with attention and are not biased in any way. Finally, the study is not financed by any public or private organization.

\section{Data Analysis \& Discussion}

\subsection{Descriptive Analysis}

For a coherent discussion and rational explanation of the results and findings, it is important to have a clear understanding of the respondent's profile which is presented in Table 1 in this study. This study collected responses from both male and female nurses working in the public hospital of Sindh. There were 146 (52.1 percent) male respondents and 134 (47.9 percent) female respondents. In addition, 90.7 percent respondents were less than 40 years of age and 63.6 percent had attended high school; only 20 respondents were having a nursing diploma, however, 72 (25 percent) respondents were also holding a postgraduate qualification. Moreover, 86 respondents (30.7 percent) possessed less than or up to five years of work experience; 112 respondents (40 percent) between 6 and 10 years; however, the sample included only 19 respondents ( 6.8 percent) held work experience between 16 and 20 years.

Table 1. Descriptive Statistics

\begin{tabular}{llccc}
\hline Demography & Indicator & Frequency & Percent & Cumulative Percent \\
\hline Gender & Male & 146 & 52.1 & 52.1 \\
Age & Female & 134 & 47.9 & 100.0 \\
& Below 30 Years & 175 & 62.5 & 62.5 \\
& 30-40 Years & 79 & 28.2 & 90.7 \\
& 41-50 Years & 22 & 7.9 & 98.6 \\
Qualification & 51-60 Years & 4 & 1.4 & 100.0 \\
& High School & 178 & 63.6 & 63.6 \\
& Nursing Diploma & 20 & 7.1 & 70.7 \\
& Undergraduate Degree & 10 & 3.6 & 74.3 \\
Experience & Postgraduate Degree & 72 & 25.7 & 100.0 \\
& 1-5 Years & 86 & 30.7 & 30.7 \\
& 6-10 Years & 112 & 40.0 & 70.7 \\
& 11-15 Years & 63 & 22.5 & 93.2 \\
& 16-20 Years & 19 & 6.8 & 100.0 \\
\hline
\end{tabular}

The measurement model was developed to determine the convergent validity, discriminant validity and construct reliability of the three latent constructs i.e. fairness perception, job clarity, and job satisfaction. The convergent validity and construct reliability were estimated by using average variance extracted (AVE) and composite reliability (CR). Whereas, the discriminant validity between the six latent variables was estimated by using two widely-used methods i.e. Fornell-Larcker and Heterotrait-Monotrait Ratio (HTMT) matrices. Table 2 also shows that the AVE of each of the five constructs is greater than 0.50 showing a good convergent validity (Hair et al., 2010). Furthermore, as shown in this table, the CR value is greater than 0.70 which shows good construct reliability (Hair et al., 2011; Hair et al., 2012; Sharif \& Bukhari, 2014; Arif et al. 22016; Afshan \& Sharif, 2016; Sharif \& Raza, 2017; Afshan et al. 2018). Moreover, in Table 3, the square root of AVE of each latent construct (which is shown in boldface on diagonal) is also greater than its inter-construct correlations showing the evidence of discriminant validity by using Fornell-Larcker criterion (Fornell \& Larcker, 1981; Molina et al. 2007). 
Table 2. Factor Loading, Cronbach Alpha, Composite Reliability and Average Variance Extracted

\begin{tabular}{|c|c|c|c|c|c|}
\hline Construct & Item & Loading & Alpha & CR & AVE \\
\hline \multirow{5}{*}{ Fairness Perception } & FP1 & 0.983 & 0.954 & 0.966 & 0.853 \\
\hline & FP2 & 0.721 & & & \\
\hline & FP3 & 0.949 & & & \\
\hline & FP4 & 0.983 & & & \\
\hline & FP5 & 0.955 & & & \\
\hline \multirow{2}{*}{ Job Clarity } & JC1 & 0.997 & 0.993 & 0.997 & 0.993 \\
\hline & $\mathrm{JC} 2$ & 0.997 & & & \\
\hline \multirow{13}{*}{ Job Satisfaction } & JS1 & 0.882 & 0.983 & 0.985 & 0.833 \\
\hline & JS2 & 0.944 & & & \\
\hline & JS3 & 0.931 & & & \\
\hline & JS4 & 0.87 & & & \\
\hline & JS5 & 0.934 & & & \\
\hline & JS6 & 0.941 & & & \\
\hline & JS7 & 0.941 & & & \\
\hline & JS8 & 0.944 & & & \\
\hline & JS9 & 0.915 & & & \\
\hline & JS10 & 0.929 & & & \\
\hline & JS11 & 0.798 & & & \\
\hline & JS12 & 0.943 & & & \\
\hline & JS13 & 0.882 & & & \\
\hline
\end{tabular}

Note $. \mathrm{CR}=$ Composite Reliability, $\mathrm{AVE}=$ Average variance extracted

To further confirm the discriminant validity, we used another method i.e. Heterotrait-Monotrait Ratio (HTMT) matrix (see Table 4) in SmartPLS 3.0. Ramayah, Cheah, Chuah, Ting, \& Memon (2016) stated "HTMT refers to the ratio of correlations within the constructs to correlations between the constructs... an estimate of what the true correlation between two constructs would be if they are perfectly measured..." (p. 62), using a more stringent criterion i.e. HTMT0.85 (Henseler, Ringle, \& Sarstedt, 2015; Kline, 2011).

Table 3. Discriminant Validity Analysis (Using Fornell-Larcker Criterion)

\begin{tabular}{cccc}
\hline & FP & JC & JS \\
\hline FP & $\mathbf{0 . 9 2 4}$ & & \\
JC & 0.569 & $\mathbf{0 . 9 9 7}$ & $\mathbf{0 . 9 1 3}$ \\
JS & 0.672 & 0.409 & \\
\hline
\end{tabular}

Note. $\mathrm{FP}=$ Fairness Perception, JC = Job Clarity, JS = Job Satisfaction

Table 4 shows that all HTMT values are less than 0.85 except 0.874 (HTMT ratio between FP and WA) which also meets HTMT0.90 threshold value (Gold, Malhotra, \& Segars, 2001; Henseler et al., 2015; Qureshi, 2015; Ahmed et al. 2017; Nadeem et al 2016; Adil \& Qureshi, 2016). Thus, it leads the author to conclude that the discriminant validity was established between the five constructs of this study using both Fornell-Larcker criterion and HTMT ratio methods.

Table 4. Discriminant Validity Analysis (Using HTMT Ration)

\begin{tabular}{|c|c|c|c|}
\hline & FP & $\mathrm{JC}$ & JS \\
\hline FP & & & \\
\hline $\mathrm{JC}$ & 0.585 & & \\
\hline JS & 0.694 & 0.413 & \\
\hline
\end{tabular}

Note. $\mathrm{FP}=$ Fairness Perception, JC = Job Clarity, JS = Job Satisfaction

Table 5 provides a complete account of hypothesis testing. This table shows fairness perception has a statistically significant and positive impact on job satisfaction $(0.492 ; p=0.000)$. However, job clarity has been found statistically insignificant to predict job satisfaction $(0.029 ; \mathrm{p}=0.249)$. In total, these two exogenous variables predict over 46 percent of the total variance in job satisfaction $\left(R^{2}=0.46\right)$ which may be considered as 'substantial' predictive accuracy of the structural model (Cohen, 1988). Also, the moderating effect of fairness perception is also insignificant on job satisfaction $(-0.069 ; \mathrm{p}=0.214)$. 
Table 5. Hypothesis testing using VB-SEM

\begin{tabular}{|c|c|c|c|c|}
\hline Predictors & Estimate & SE & T-Value & Sig \\
\hline FP & 0.492 & 0.078 & 6.270 & 0.000 \\
\hline $\mathrm{JC}$ & 0.029 & 0.043 & 0.678 & 0.249 \\
\hline JCxFP & -0.069 & 0.087 & 0.794 & 0.214 \\
\hline Adj. $R^{2}$ & & & & \\
\hline
\end{tabular}

Note. Exogenous Variable = Job Satisfaction

\section{Conclusion \& Policy Implication}

The main objective of this study was to ascertain the impact of job clarity on nurses' job satisfaction in the public hospitals of Sindh province of Pakistan. The results presented a valid and reliable measurement model so that a structural model could be built upon it for testing research hypotheses. Results indicate that job clarity has an insignificant impact on job satisfaction among nurses in Pakistan. Moreover, fairness perception does not moderate rather, it is found to be a strong predictor of nurses' job satisfaction. In other words, people who have a lack of clarity about tasks, roles, and responsibilities often end up affecting their outcomes. Clarity in the assigned role is essential to ensure that the individual is capable of achieving what he/she is destined for. In a similar manner, job clarity is crucial for employees to foster their work understanding and hence, express satisfaction with the job (Kroposki et al., 1991). In the views of Donnelly (1975), job clarity is important to help employees perform at the best of their capabilities. Without clear roles and responsibilities, an organization cannot simply expect its employees to showcase positive behaviors and outcomes (Kim, 2009). Based on the evidence from prior studies, suggesting that job clarity factor is significantly in correlation with employees job satisfaction (Kim, 2009; Reid et al., 2008), this assertion was taken forward to examine how this association results amongst nurses in public sector hospitals in Sindh, Pakistan. Keeping these theoretical evidence beforehand, the present study attempted to test job clarity and job satisfaction. The PLS path modeling approach found job clarity as a statistically insignificant predictor of nurses' job satisfaction. This might be attributed to the fact that there is a shortage of nurses in the healthcare sector of Pakistan and people who choose nursing as their profession tend to understand that they need to work hard to stay on their nursing job. Consequently, in light of the present scenario in Pakistan, male and female nurses are compelled to work as per the directions of hospital management. Besides, data were collected from the public hospitals where a large number of nurses' appointments are made based on political connections or even a phone call from a senior government official, leader of a political party, or bureaucrat. It results in nurses are least bothered about the job clarity. They tend to find their job satisfaction in other extrinsic motivators. Sometimes, the lack of clear information about job tasks results in role ambiguity that may have an undesirable impact on employee job satisfaction (Kroposki, et al., 1999).

The finding underlines the need for medical institutes to ensure that they allocate work evenly and so the reward across their workforce. Particularly for nurses, the present study has outlined that they valued fairness perception and through it, strengthened usage of job clarity features to boost job satisfaction. HR policies and general policy makers in the organization have a greater role in this regards (Weaver \& Trevina, 2001) to ensure that the work is divided on fair grounds and so the rewards. The finding is crucial learning for top management and people in key authorities regarding how fairness perceptions can be strategically used as an important work factor to positively enhance employee behaviors and outcomes. There are far greater benefits of fairness perceptions that organizations need to unveil (Choi \& Mattila, 2005) in order to ensure the strategic achievement of both individual and organizational objectives.

\section{References}

Adams, A., \& Bond, S. (2000). Hospital nurses' job satisfaction, individual and organizational characteristics. Journal of Advanced Nursing, 32(3), 536-543. https://doi.org/10.1046/j.1365-2648.2000.01513.x

Adil, M. S., \& bin Ab Hamid, K. (2017). Impact of individual feelings of energy on creative work involvement: A mediating role of leader-member exchange. Journal of Management Sciences, 4(1), 82-105. https://doi.org/10.20547/jms.2014.1704105

Afshan, S., \& Sharif, A. (2016). Acceptance of mobile banking framework in Pakistan. Telematics and Informatics, 33(2), 370-387. https://doi.org/10.1016/j.tele.2015.09.005

Afshan, S., Sharif, A., Waseem, N., \& Frooghi, R. (2018). Internet banking in Pakistan: an extended technology acceptance perspective. International Journal of Business Information Systems, 27(3), 383-410. https://doi.org/10.1504/IJBIS.2018.089863 
Ahmed, U., Shah, M. H., Siddiqui, B. A., Shah, S. A., Dahri, A. S., \& Qureshi, M. A. (2017). Troubling job demands at work: Examining the deleterious impact of workload and emotional demands on work engagement. International Journal of Academic Research in Business and Social Sciences, 7(6), 96-106. https://doi.org/10.6007/IJARBSS/v7-i6/2949

Arif, I., Afshan, S., \& Sharif, A. (2016). Resistance to adopt mobile banking in a developing country: evidence from modified TAM model. Journal of Finance and Economics Research, 1(1), 23-38. https://doi.org/10.20547/jfer1601104

Bhatti, G., Islam, T., Mirza, H., \& Hadi, F. (2015). The relationships between LMX, Job satisfaction, and turnover intention. Science International, 27(2). 118-127.

Blumenthal, S., Lavender, T., \& Hewson, S. (1999). Role clarity, perception of the organization and burnout amongst support workers in residential homes for people with intellectual disability: A comparison between a National Health Service trust and a charitable company. Occupational Health and Industrial Medicine, l(40), 28-37.

Boyt, T. E., Lusch, R. F., \& Naylor, G. (2001). The role of professionalism in determining job satisfaction in professional services: A study of marketing researchers. Journal of Service Research, 3(4), 321-330. https://doi.org/10.1177/109467050134005

Bray, S. R., \& Brawley, L. R. (2002). Role efficacy, role clarity, and role performance effectiveness. Small Group Research, 33(2), 233-253. https://doi.org/10.1177/104649640203300204

Brief, A. P., Schuler, R. S., \& Van Sell, M. (1981). Managing job stress. In Managing job stress.

Bushra, F., Ahmad, U., \& Naveed, A. (2011). Effect of transformational leadership on employees job satisfaction and organizational commitment in banking sector of Lahore (Pakistan). International Journal of Business and Social Science, 2(18), 261-267.

Chang, Y. H., Li, H.., Wu, C. M. \& Wang, P. C. (2010), The influence of personality traits on nurses' job satisfaction in Taiwan. International Nursing Review, 57(4), 478-484. https://doi.org/10.1111/j.1466-7657.2010.00825.x

Chen, G., Gully, S. M., \& Eden, D. (2001). Validation of a new general self-efficacy scale. Organizational Research Methods, 4(1), 62-83. https://doi.org/10.1177/109442810141004

Deloitte, (2015). Global health care outlook Common goals, competing priorities. Retrieved from http://www2.deloitte.com/content/dam/Deloitte/global/Documents/Life-Sciences-Health-Care/gx-lshc-2015 -health-care-outlook-global.pdf

Dillman, D. A. (1978). Mail and telephone surveys: The Total Design Method, 19, Wiley New York.

Fornell, C., \& Larcker, D. F. (1981). Evaluating structural equation models with unobservable variables and measurement error. Journal of Marketing Research, 39-50. https://doi.org/10.1177/002224378101800104

Gold, A. H., Malhotra, A., \& Segars, A. H. (2001). Knowledge management: An organizational capabilities perspective. Journal of Management Information Systems, 18(1), 185-214. https://doi.org/10.1080/07421222.2001.11045669

Hair, J. F., Ringle, C. M., \& Sarstedt, M. (2011). PLS-SEM: Indeed a Silver Bullet. Journal of Marketing Theory and Practice, 18(2), 139-152. https://doi.org/10.2753/MTP1069-6679190202

Hair, J. F., Ringle, C. M., \& Sarstedt, M. (2013). Editorial-partial least squares structural equation modeling: Rigorous applications, better results and higher acceptance. Long Range Planning, 46(1-2), 1-12. https://doi.org/10.1016/j.lrp.2013.01.001

Hair, J. F., Ringle, C. M., \& Sarstedt, M. (2013). Partial least squares structural equation modeling: Rigorous applications, better results and higher acceptance. 46(1), 1-12. https://doi.org/10.1016/j.lrp.2013.01.001

Hair, J. F., Sarstedt, M., Ringle, C. M., \& Mena, J. A. (2012). An assessment of the use of partial least squares structural equation modeling in marketing research. Journal of the Academy of Marketing Science, 40(3), 414-433. https://doi.org/10.1007/s11747-011-0261-6

Henseler, J., Ringle, C. M., \& Sarstedt, M. (2015). A new criterion for assessing discriminant validity in variance-based structural equation modeling. Journal of the Academy of Marketing Science, 43(1), 115-135. https://doi.org/10.1007/s11747-014-0403-8

Jansen, P. G., Kerkstra, A., Abu-Saad, H. H., \& Van Der Zee, J. (1996). The effects of job characteristics and 
individual characteristics on job satisfaction and burnout in community nursing. International Journal of Nursing Studies, 33(4), 407-421. https://doi.org/10.1016/0020-7489(95)00060-7

Kahn, R. L., Wolfe, D. M., Quinn, R. P., Snoek, J. D., \& Rosenthal, R. A. (1964). Organizational stress: Studies in role conflict and ambiguity. Retrieved from http://psycnet.apa.org/record/1965-08866-000

Kelly, J.P. and Hise, R.T. (1980). Role conflict, role clarity, job tension and job satisfaction in the brand manager position, Journal of the Academy of Marketing Science, 8(2), 120-137. https://doi.org/10.1007/BF02721978

Khaliq, M. J., Rehman, M., \& Rashid, M. (2011). The role of human resource management and nurses' job satisfaction in medical service organizations. African Journal of Business Management, 5(3), 974-986.

Kim, S. (2009). IT Employee Job Satisfaction in the Public Sector. International Journal of Public Administration, 32(12), 1070-1097. https://doi.org/10.1080/01900690903170303

Kline, R. B. (2011). Principles and practice of structural equation modeling. New York: Guilford Press. Teo, T. S. $\mathrm{H}$.

Konovsky, M. A., \& Cropanzano, R. (1991). Perceived fairness of employee drug testing as a predictor of employee attitudes and job performance. Journal of Applied Psychology, 76(5), 698-707. https://doi.org/10.1037/0021-9010.76.5.698

Kothari, C. (2004). Research methodology: Methods and techniques: New Age International.

Kroposki, M., Murdaugh, C., Tavakoli, A., \& Parsons, M. (1999). Role clarity, organizational commitment, and job satisfaction during hospital reengineering. Nursing Connections, 12(1), 27-34.

Kumar, R., Ahmed, J., Shaikh, B. T., Hafeez, R., \& Hafeez, A. (2013). Job satisfaction among public health professionals working in public sector: a cross sectional study from Pakistan. Human Resources for Health, 11(1), 2-5. https://doi.org/10.1186/1478-4491-11-2

Locke, E. A., \& Latham, G. P. (2002). Building a practically useful theory of goal setting and task motivation: A 35-year odyssey. American Psychologist, 57(9), 705. https://doi.org/10.1037/0003-066X.57.9.705

Mahmud, A., \& Parkhurst, M. (2007). The role of the health care sector in expanding economic opportunity. Corporate Social Responsibility Initiative Report, 21, 79-94.

Meleis, A. I. (1975). Role insufficiency and role supplementation: A conceptual framework. Nursing Research, 24(6), 264-271. https://doi.org/10.1097/00006199-197507000-00004

Meleis, A. I., \& Swendsen, L. A. (1978). Role supplementation: An empirical test of a nursing intervention. Nursing Research, 27(1), 11-18. https://doi.org/10.1097/00006199-197801000-00003

Nadeem, S., Abdullah, N. A. H. B. N., Azeem, M., Qureshi, M. A., \& Saqib, M. (2016). The impact of Manager's personal values and awareness on the sustainable behavior. International Journal of Economic Perspectives, 10(4), 710-725.

Qureshi, M. A. (2015). Human resource practices in Pakistan banking sector: A conceptual framework including personality traits, emotional intelligence and employee performance. International Journal of Scientific and Research Publications, 5(1), 78-95.

Qureshi, M. A., \& bin Ab Hamid, K. (2017). Impact of supervisor support on job satisfaction: A moderating role of fairness perception. International Journal of Academic Research in Business and Social Sciences, 7(3), 235-242.

Qureshi, M. A., Waseem, N., Qureshi, J. A., \& Afshan, S. (2018). Impact of Organizational Commitment on Readiness for Change: A Case of Higher Learning Institutions of Karachi. Journal of Independent Studies and Research, 16(1), 1-14.

Ramayah, T., Cheah, J., Chuah, F., Ting, H., \& Memon, M. A. (2016). Partial Least Squares Structural Equation Modeling (PLS-SEM) using SmartPLS 3.0: An Updated Guide and Practical Guide to Statistical Analysis.

Sharif, A. A., \& Bukhari, S. W. (2014). Determinants of Brand Equity of QMobile: A case study of Pakistan. Journal of Management Sciences, 1(1), 49-60. https://doi.org/10.20547/jms.2014.1401104

Sharif, A., \& Raza, S. A. (2017). The influence of hedonic motivation, self-efficacy, trust and habit on adoption of internet banking: a case of developing country. International Journal of Electronic Customer Relationship Management, 11(1), 1-22. https://doi.org/10.1504/IJECRM.2017.086750

Smerek, R. E., \& Peterson, M. (2007). Examining Herzberg's theory: Improving job satisfaction among 
non-academic employees at a university. Research in Higher Education, 48(2), 229-250. https://doi.org/10.1007/s11162-006-9042-3

Suan, C. L., \& Nasurdin, A. M. (2013). Role clarity, supervisory support, peer support, and work engagement of customer-contact employees in hotels: a future research agenda Tourismos. An International Multidisciplinary Journal of Tourism, 8(1), 315-329.

Swayne, L. E., Duncan, W. J., \& Ginter, P. M. (2012). Strategic Management in Health Care. (J. Klich, M. Korona, \& J. Kutner, Trans., J. Klich, Ed.) (pp. XV, [1], 900). Warszawa : Lex a Wolters Kluwer business.

Teas, R. K., Wacker, J. G., \& Hughes, R. E. (1979). A path analysis of causes and consequences of salespeople's perceptions of role clarity. Journal of Marketing Research, 16(3), 355-369. https://doi.org/10.1177/002224377901600308

Terje, S., Göran, S., \& Sander, S. (2011). Service quality and turnover intentions as perceived by employees: antecedents and consequences. Personnel Review, 40(2) 205-221. https://doi.org/10.1108/00483481111106084

Troyer, L., Mueller, C. W., \& Osinsky, P. I. (2000). Who's the boss? A role-theoretic analysis of customer work. Work and Occupations, 27(3), 406-427. https://doi.org/10.1177/0730888400027003007

Wetzels, M., de Ruyter, K., \& Bloemer, J. (2000). “Antecedents and consequences of role stress of retail sales persons". Journal of Retailing and Consumer Services, 7(2), 65-75. https://doi.org/10.1016/S0969-6989(99)00011-9

Wright, B. E., \& Davis, B. S. (2003). Job satisfaction in the public sector: The role of the work environment. The American Review of Public Administration, 33(1), 70-90. https://doi.org/10.1177/0275074002250254

Zeffane, R., \& Al Zarooni, H. A. M. (2008). The influence of empowerment, commitment, job satisfaction and trust on perceived managers' performance. International journal of Business Excellence, 1(1-2), 193-209. https://doi.org/10.1504/IJBEX.2008.017574

\section{Copyrights}

Copyright for this article is retained by the author(s), with first publication rights granted to the journal.

This is an open-access article distributed under the terms and conditions of the Creative Commons Attribution license (http://creativecommons.org/licenses/by/4.0/). 